\title{
Correction to: Erratum: Measurement of serum trace elements levels in patients with juvenile idiopathic arthritis
}

\author{
Yasser A. Soliman ${ }^{1}$, Nashwa I. Hashaad ${ }^{1 *}$, Shuzan A. Mohammed² and Hala A. El-Nouty ${ }^{1}$
}

\section{Correction to: Egypt Rheumatol Rehabil 44, 43 (2017) https://doi.org/10.4103/1110-161X.200839}

The last author Hala A. El-Nouty's name was inadvertently omitted from the author list of the original article [1].

Hala A. El-Nouty's name is included in the author list of this Correction and has already been added to the original article.

\section{Author details}

'Department of Rheumatology, Physical Medicine and Rehabilitation, Faculty of Medicine, Benha University, Benha, Egypt. ${ }^{2}$ Department of Biochemistry, Faculty of Medicine, Benha University, Benha, Egypt.

Published online: 15 March 2021

\section{Reference}

1. Soliman et al (2017) Erratum: Measurement of serum trace elements levels in patients with juvenile idiopathic arthritis. Egypt Rheumatol Rehabil 44:43. https://doi.org/10.4103/1110-161X.200839

\footnotetext{
The original article can be found online at https://doi.org/10.4103/1110-161X. 200839.

*Correspondence: nashwa_hashaad@yahoo.com

1 Department of Rheumatology, Physical Medicine and Rehabilitation, Faculty of Medicine, Benha University, Benha, Egypt

Full list of author information is available at the end of the article
}

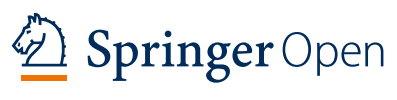

(c) The Author(s). 2021 Open Access This article is licensed under a Creative Commons Attribution 4.0 International License which permits use, sharing, adaptation, distribution and reproduction in any medium or format, as long as you give appropriate credit to the original author(s) and the source, provide a link to the Creative Commons licence, and indicate if changes were made. The images or other third party material in this article are included in the article's Creative Commons licence, unless indicated otherwise in a credit line to the material. If material is not included in the article's Creative Commons licence and your intended use is not permitted by statutory regulation or exceeds the permitted use, you will need to obtain permission directly from the copyright holder. To view a copy of this licence, visit http://creativecommons.org/licenses/by/4.0/. 